\title{
Techno-Commercial Assessment of Concurrent Municipal Brown Field Reclamation Procedures: A Pivotal Case Study of Jawahar Nagar Dump Site
}

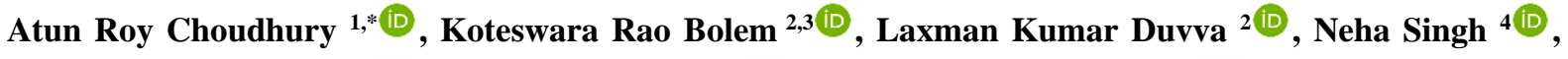 \\ Praveen Kumar Moota ${ }^{2}$ (D), Leelavathi Anagani ${ }^{2}$ (D), Lakshmi Prasad Boyina ${ }^{1,2}$ (D), Abitha Begum Syed \\ Umar $^{5}$ (D) \\ 1 Chadwick's FSM Laboratory, Banka BioLoo Limited, 56. Nagarjuna Hills Road, Punjagutta, Hyderabad, India \\ 2 Institute of Science and Technology, Jawaharlal Nehru Technological University, Hyderabad, India \\ 3 Department of Environment \& Sustainable Development, Environment Protection Training and Research Institute \\ (EPTRI) 91/4, Gachibowli, Hyderabad, India \\ 4 Laboratory- HWMP, Ramky Enviro Engineers Limited, Dundigal Village, Hyderabad, India \\ 5 Department of Civil Engineering, Faculty of Engineering and Technology, Annamalai University, Annamalai Nagar, \\ Tamil Nadu, India \\ * Correspondence: atnroy10@gmail.com (A.R.C.);
}

Scopus Author ID 57213420861

Received: 12.04.2021; Revised: 5.06.2021; Accepted: 8.06.2021; Published: 27.06.2021

\begin{abstract}
The quantity of municipal solid waste (MSW) generation is escalating at an alarming rate with every passing year alongside the modernization of our economy. Unfortunately, the majority of this waste remains uncollected or ends up in open dumping and followed by uncontrolled burning. Citing the deep-rooted consequences, open dumping should be abandoned, and scientific interventions should be aggressively exercised to reclaim the municipal brownfields. The present research undertook the judicial task of assessing the comparative feasibility of biomining and scientific capping as a technology selection for reclamation of about a decade-old 120 million tons of waste chunk laying at Jawahar Nagar dump yard. Primary dump samples were collected from various locations, considering depth as a variable. At the same time, leachate and groundwater samples were collected from Malkaram lake and preinstalled borewells receptively. Additionally, the ambient air quality and noise level also been ascertained within the buffer zone. The blended representative solid sample was segregated using a $70 \mathrm{~mm}$ mesh trommel into organic and inorganic fractions. The organic fraction was composted using a lab-scale aerobic static pile composting (ASPC) while the trommel reject was processed as refusederived fuel (RDF). Evidently, the compost lagged quality and depicted nutrient deficiency. In contrast, the burning of RDF produced siloxane gas significantly due to elevated silicon levels in the primary waste. Furthermore, due to the prolonged leaching tenure and seasonal dilution, the concentration of legacy leachate was relatively weaker. Borewell samples collected from a depth of 20 feet also portrayed minor contamination up to 500 meters horizontal radius. The issue of leachability can solely be resolved with the capping of the existing dump, and the end product quality derived from the biomining process is highly questionable. Thus, handling such large quantity capping is a befitting option over biomining for Jawahar Nagar dumpsite.
\end{abstract}

Keywords: municipal solid waste; legacy dump; bio-mining; scientific capping; reclamation.

(C) 2021 by the authors. This article is an open-access article distributed under the terms and conditions of the Creative Commons Attribution (CC BY) license (https://creativecommons.org/licenses/by/4.0/). 


\section{Introduction}

Presently, in India, due to rapid urbanization and industrialization, the generation of MSW has been increasing tremendously and is also expected to continue a similar trend in the future [1-4]. Annually, the comprehensive urban MSW generation in India is more than 62 million tons. Metro cities are the mammoth contributor of the entire chunk, and waste production had already reached an alarming figure of 50,000 tonnes/day. While the waste generation from the tier 2 cities is also rigorously escalating and presently contributes up to 20,000 tones/day [4]. A study conducted by the central pollution control board (CPCB) revealed MSW generation in India is increasing at a distressing rate of $5 \%$ per annum with a sharp escalation in the quantities of domestic hazardous waste [4]. With major financial constraints, the inefficacy of collection, treatment, and disposal incurs further reasons to worry.

So far, India has miserably failed to set up wholesome source segregation and collection method. Presently, the country spends more than $60 \%$ of its annual waste management budget only on collection. Besides, only $20 \%$ or less of the collected materials are scientifically handled and treated. Citing the statistics, it is evident that most of the MSW is simply dumped on the low laying grounds located somewhere on the outskirts of the cities. The precipitation, infiltration, surface water runoff, bird menace, rodent interference etc., triggers the vulnerability of waste and leads to mal odor, ground and surface water contamination, human and environmental health deterioration [5]. Further, the perseverance of the inorganic and inert fractions leads to soil contamination, poses a fire threat, and also may incur carcinogenicity and acute toxicity among the animals [6].

There are numerous techniques for the reclamation and remediation of the dumpsites, including capping and closure, in-situ vitrification, sub-surface cut-off walls, and waste biomining [7,8]. Waste biomining is a stable way to eliminate the entire range of problems associated with open dumping and reclaim valuable land [9]. Several instances include reclamation of Mumbai Gorai dump yard by IL \& FS Environment, 70 - 80 years old 12,00,000 tons of dump clearance by Nagar Nigam Indore within a short span of 3 years, and many more. But the process of biomining is highly sensitive and case-specific. The success of the process solely depends on factors such as characteristics of the waste, efficacy of the effective microorganism culture, acceptability of the processed end product at the local market, etc. [1012]. Contrarily, though the scientific capping is not an end-to-end solution but still advisable when the quantity of waste is gigantic, land scarcity is prevalent, no nearby industries to consume the end products etc. Mehta et al. (2018) [13] have supported the above claim based on assessing location-specific MSW dump reclamation case studies. While in another Nagpurbased case study conducted by Ashootosh et al. (2020) [14] reported the superiority of the biomining process over simple land capping due to the favorability of the local conditions. Capping eliminates environmental interference and thereby reduces biosphere contamination and leachate generation. Further, it captivates rodent and vector breeding and thereby curtails the spreading of communicable diseases and improves aesthetics. But right consolidation through compaction and execution is of utmost necessity in the above case as non-compaction and faulty sloping will easily lead to heavy settlement and slope failure [15,16].

The present study has been pursued with the primary objective to run a technocommercial assessment between scientific capping and biomining. At the same time, the secondary objective was to ascertain the level of contamination and propose mitigative measures. 


\section{Materials and Methods}

The primary tasks performed were the sampling of the composite specimens from various locations and layers, design of lab-scale comparative experiment, and conduction of the thorough investigation and analysis of each of the samples. A detailed description of the work is delineated below.

\subsection{Study area.}

Spanning over 350 acres of a precious piece of land at the outskirts of Hyderabad city, Jawahar Nagar's dumping yard was brutally utilized by the Greater Hyderabad Municipal Corporation (GHMC) for open dumping for a prolonged tenure of 10 years. It housed nearly 12 lakh metric tons of heterogeneous solid and domestic hazardous waste and continues polluting until 2015 until the Ramky group was offered to cap the legacy dumping and scientifically handle the site. The present study has been facilitated at Hyderabad Municipal Solid Waste Limited, formerly known as Jawahar Nagar dump yard, to analyze and assess the feasibility of bio-mining as handling and management alternate to the existing practice of scientific capping. The epicenter of the processing and disposal facility is lying approximately on the cross-section of $17^{\circ} 31^{\prime} 24.45^{\prime \prime} \mathrm{N}$ and $78^{\circ} 35^{\prime} 23.37^{\prime \prime} \mathrm{E}$. As per the contract, the comprehensive legacy dumping to be capped in three phases over about 150 acres of area, and Ramky has significantly entered phase two of the operation within five years by successfully capping more than half of the operation the legacy footprint.

\subsection{Sampling methodology.}

The waste pile was divided into three layers, namely, base, middle, and top. A uniform amount of sample was collected from the successive layers of all five different corners, covering the north, south, east, west, and center of the garbage pile. Sampling inspections were performed using a manual auger, besides large samples were collected using a JCB excavator. The top six-inch layer of the pile was removed to avoid contamination while collecting the samples, and 5-10 kg of sample was collected from each location. Further, intermediate and bottom layer samples were collected by digging a $500 \mathrm{~mm}$ diameter hole through the heap. A composite was prepared by a homogenized blending of all the fifteen grub samples. The blend was distributed into four equal quadrants, and the top and bottom quadrants were eliminated diagonally while the left-over quadrants were mixed thoroughly. This process was repeated until a sample of the required bulk of $20 \mathrm{~kg}$ is obtained.

Surface and subsurface water samples from borewells were collected in and around the facility. Piezometric monitoring borewells located near the landfills were utilized for the subsurface sample collection, while a rainwater pond turned leachate lake named Malkaram was determined as the primary source for leachate collection. Buffer samples were collected from Ambedkar Nagar, the nearby colony exiting at a distance of only 300 meters.

\subsection{Lab-scale experimentation.}

The representative sample was characterized for composition and further screened through a $70 \mathrm{~mm}$ mesh size trommel. The trommel permeate was considered as the organic fraction, while the reject was mostly inorganics and inert. The organics were subjected to ASPC. The quantity of the air required is arrived at using the method delineated below (Figure 
1).

MSW Pile size: $2 \mathrm{~m} \times 0.5 \mathrm{~m} \times 0.5 \mathrm{~m}$

Volume of pile: $0.5 \mathrm{~m}^{3}$

Average Density of MSW: $620 \mathrm{Kg} / \mathrm{m}^{3}$

Weight of pile: $310 \mathrm{Kg}$

Nitrogen required for matured compost: $9300 \mathrm{mg} / \mathrm{kg}$ dry

: $9300 \times 310 \mathrm{mg}$

$: 2.88 \times 10^{6} \mathrm{mg}$

$: 2.88 \mathrm{Kg}$

Total air required: $2.88 \times 100 / 76$ [as Nitrogen in air is $76 \%$ by weight]

$: 3.79 \mathrm{Kg}$ of dry air

: 3.79/1.225 $\mathrm{m}^{3}$ [@ 15 deg C density of air $1.225 \mathrm{~kg} / \mathrm{m}^{3}$ ]

$: 3.1 \mathrm{~m}^{3}$

This air is to be supplied for $100 \mathrm{~min} /$ day for $0.5 \mathrm{~m}$ pile

Airflow rate required: $3.1 \times 60 / 100=1.86 \mathrm{~m}^{3} / \mathrm{h}$ (for the practical purpose, a flow rate of $2 \mathrm{~m}^{3} / \mathrm{h}$ was maintained).

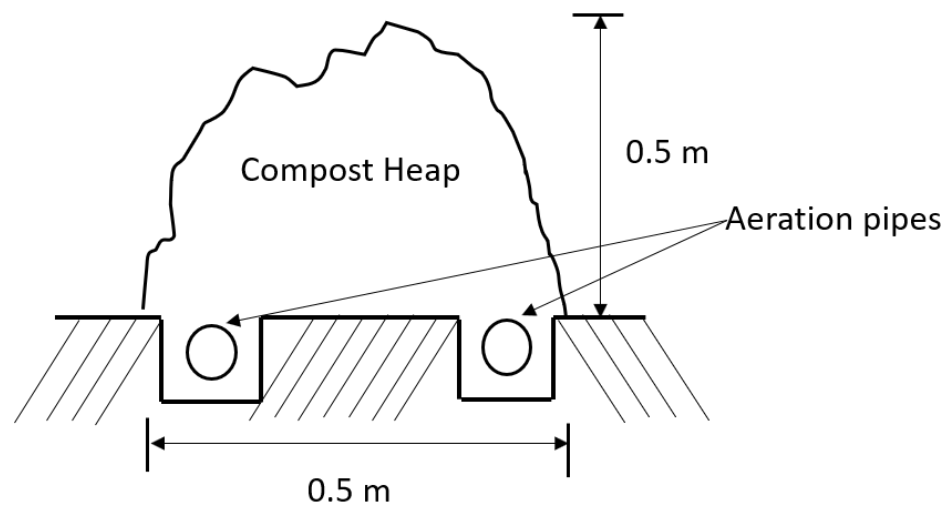

Figure 1. Cross-section of ASPC process.

The maturation period was considered as 28 days, and post-maturation, the stabilized material was further cured for 24 hours and screened using $12 \mathrm{~mm}$ and $4 \mathrm{~mm}$ trommel, respectively, to obtain the desired product quality and particle size.

The trommel reject was evenly spreader on the copper trays and dried in an oven at $105^{\circ} \mathrm{C}$ for 2 hours. The dried material was micronized to $50 \mathrm{~mm}$ or below using a scissor, and inert such as glass, sand, stone etc., were segregated manually [17].

Concurrently, a bench-scale capped landfill prototype was built using the belowmentioned procedure to evaluate the factors such as settlement and slope stability. A $30 \mathrm{~mm}$ thick low permeable soil was laid on the top of the waste, followed by a $60 \mathrm{~mm}$ layer of compacted clay liner (CCL). Each join between successive liner material was closely monitored. A $1.5 \mathrm{~mm}$ thick HDPE liner was placed on the top of the CCL. A 285 GSM geotextile membrane was placed as the above successive layer followed by a $15 \mathrm{~mm}$ thick drainage media layer. A further layer of geotextile membrane was placed on top of the drainage media to stabilize better, grip, and strengthen. The top vegetative soil layer of $45 \mathrm{~mm}$ thickness was laid off on top of the geotextile media, and St. Augustine grass was rooted $[18,19]$.

2.4. Sample analysis.

$\mathrm{pH}$, Electrical Conductivity (EC), and Turbidity of the samples were analyzed using 
$\mathrm{pH}$, EC-TDS, and Nephelometer of Mettler Toledo. The $\mathrm{pH}$ meter was calibrated with the buffer solution of 4.0, $7.0 \& 9.12$ at a controlled temperature. EC-TDS meter was calibrated with $0.1 \mathrm{M} \mathrm{KCL}$ having $12.8 \mathrm{mS} / \mathrm{cm}$ of conductivity. Nephelometer was calibrated with Formazine solution of $10 \& 100$ NTU. Total Dissolved Solids (TDS), (mg/L) was performed using the gravimetric method at $180^{\circ} \mathrm{C}$ in the oven.

Titrimetric parameters such as Total Alkalinity as $\mathrm{CaCO}_{3}(\mathrm{mg} / \mathrm{L})$, Total Hardness as $\mathrm{CaCO}_{3}(\mathrm{mg} / \mathrm{L})$, Chloride as $\mathrm{Cl}^{-}(\mathrm{mg} / \mathrm{L})$, Calcium as $\mathrm{Ca}^{2+}(\mathrm{mg} / \mathrm{L})$, Residual Free Chlorine (RFC), (mg/L) were analyzed using APHA (American Public Health Associations) method, $23^{\text {rd }}$ Edition, 2017. Total Kjeldahl Nitrogen $(\mathrm{mg} / \mathrm{L})$ and Ammonical Nitrogen $(\mathrm{mg} / \mathrm{L})$ were performed through distillation followed by titration with $\mathrm{H}_{2} \mathrm{SO}_{4}$ as a titrant. Sulfide as $\mathrm{S}^{2-}$ was done with the Iodometric method after distillation. Each titrimetric parameter was analyzed in triplicate after standardizing the titrant with required reagents and cross-checked by keeping a standard.

Sodium as $\mathrm{Na}(\mathrm{mg} / \mathrm{L})$ and Potassium as $\mathrm{K}(\mathrm{mg} / \mathrm{L})$ were performed using Flame Photometer. The photometer was calibrated with different standards from 10 to 100 (mg/L) standard solutions. The leachate sample was diluted enough to get the value within the standard range and cross-checked with check standards at the same time.

Chemical Oxygen Demand (COD), (mg/L) was performed using the open reflux method for 2 hours at $150^{\circ} \mathrm{C}$ in COD Digestor. Biochemical Oxygen Demand (BOD), (mg/L) was performed using the alkali iodide azide method for 3 days. The samples were kept in a BOD incubator at $27^{0} \mathrm{C}$ for 3 days. It was kept in duplicate to have a check on quality control.

Sulfate was analyzed using the gravimetric method instead of turbidimetric or through UV-Visible spectrophotometer as its concentration was found to be more than $40 \mathrm{mg} / \mathrm{L}$. Nitrate as $\mathrm{NO}_{3}{ }^{-}$was analyzed after filtration at $220-275 \mathrm{~nm}$, while Hexavalent Chromium as $\mathrm{Cr}^{6+}$ was analyzed at $540 \mathrm{~nm}$ in the UV-Vis. Parameters like Cyanide as $\mathrm{CN}^{-}$, Fluoride as $\mathrm{F}^{-}$, and Phenolic Compounds were gone through a distillation process followed by UV-Vis. The distillation process ensures the removal of interferences presents either positive or negative. For the parameters like Total Iron or Ferric Iron, the samples were digested properly with the required reagents on the hot plate before analyzing in UV-Vis.

For the metal analysis, the water samples were digested at a temperature of $100^{\circ} \mathrm{C}$ using aqua regia as a medium. The samples were digested to one-fourth of the volume on a hot plate. The recommended wavelengths as per APHA $3120 \mathrm{~B}$ were selected for each of the metals. The standard graph was plotted for each of the metals before analysis and crossed checked with the check standard simultaneously.

Parameters such as bulk density and particle size were performed through the certified beaker and sieve. The percentage of moisture content was estimated using the oven by keeping the compost sample for 2 hours at $105^{\circ} \mathrm{C}$. C/N ratio was estimated through a CHNS analyzer keeping sulfanilamide as a check standard. The analysis was performed by extracting the desired component in the desired solution prescribed in the method followed by converting the same from $\mathrm{mg} / \mathrm{L}$ to $\mathrm{mg} / \mathrm{Kg}$.

\section{Results and Discussion}

An exhaustive bench study has been pursued, and real-time samples were collected and analyzed for all possible parameters to determine the pros and cons attributed to both processes. The investigation begins by collecting the samples and concluded with impact assessment studies inclusive of the buffer zone. Both solid, liquid, and gaseous samples were precisely 
investigated to opt for the best solution. A detailed finding of the investigation is summarized below.

The solid representative sample was primarily characterized through a manual separation process, and the results are portrayed in Figure 2.

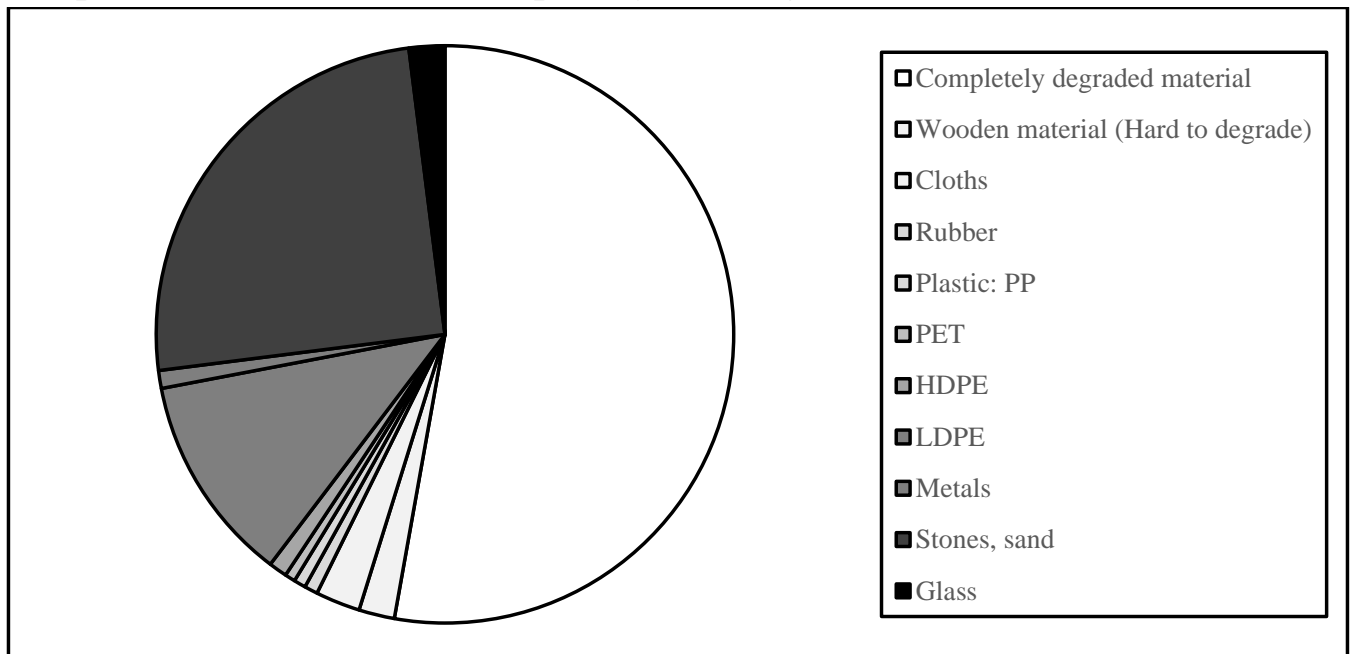

Figure 2. Composition of the legacy dump.

\subsection{Compost characterization.}

ASPC of the organic fraction has resulted in a recovery of $46.7 \%$ of the initial load. While $53.3 \%$ of the influent mass was inert and barely degradable fraction contributes to reject, the rest, $4.1 \%$, is miscellaneous process loss. The processed compost was extensively analyzed, including for metal contamination, and the same is tabulated in Table 1.

Table 1. Characteristics of compost sourced from the legacy dump.

\begin{tabular}{|c|c|c|c|c|}
\hline No. & Parameter & Unit & Result & Standard ${ }^{1}$ \\
\hline 1. & Physical State & - & Solid & - \\
\hline 2. & Color & -- & Dark Brown & $\begin{array}{l}\text { Dark Brown to } \\
\text { Black }\end{array}$ \\
\hline 3 & Particle Size & $\%$ & 94.2 & $\begin{array}{l}\text { Min } 90 \% \text { Dry } \\
\text { Weight Passing } \\
\text { through } 4 \mathrm{~mm} \\
\text { sieve }\end{array}$ \\
\hline 4. & Odor & - & $\begin{array}{l}\text { Absence of foul } \\
\text { odor }\end{array}$ & $\begin{array}{l}\text { Absence of foul } \\
\text { odor }\end{array}$ \\
\hline 5. & $\mathrm{pH}(10 \%$ Solution $)$ & - & 7.36 & $6.5-7.5$ \\
\hline 6. & EC (10\% Solution) & $\mu \mathrm{mho} / \mathrm{cm}$ & 3388 & $4.0 \mathrm{dsm}-1$ \\
\hline 7. & Bulk Density & $\mathrm{gm} / \mathrm{cc}$ & 0.90 & $<1.0$ \\
\hline 8. & Moisture Content & $\%$ & 21.9 & $15-25$ \\
\hline 9. & C/N Ratio & - & 39.11 & $<20: 1$ \\
\hline 10. & Organic Carbon (OC) & $\%$ & 10.2 & $>12.0$ \\
\hline 11. & Total Nitrogen (TN) & $\%$ & 0.6 & $>0.8$ \\
\hline 12. & Potassium as $\mathrm{K}_{2} \mathrm{O}$ & $\%$ & 0.31 & $>0.4$ \\
\hline 13. & Phosphate as $\mathrm{P}_{2} \mathrm{O}_{5}$ & $\%$ & 0.28 & $>0.4$ \\
\hline 14. & $\begin{array}{l}\text { Total Nitrogen as } \mathrm{N} \text {, } \\
\text { Phosphate as } \mathrm{P}_{2} \mathrm{O}_{5} \text {, and Potash } \\
\text { as } \mathrm{K}_{2} \mathrm{O}(\mathrm{NPK})\end{array}$ & - & 0.82 & $<1.2$ \\
\hline 15. & Arsenic as As & $\mathrm{mg} / \mathrm{kg}$ & 3.8 & 10.0 \\
\hline 16. & Lead as $\mathrm{Pb}$ & $\mathrm{mg} / \mathrm{kg}$ & 31.8 & 100 \\
\hline 17. & Cadmium as $\mathrm{Cd}$ & $\mathrm{mg} / \mathrm{kg}$ & 3.24 & 5.0 \\
\hline 18. & Chromium as $\mathrm{Cr}$ & $\mathrm{mg} / \mathrm{kg}$ & 20.6 & 50.0 \\
\hline 19. & Nickel as Ni & $\mathrm{mg} / \mathrm{kg}$ & $<0.2$ & 50.0 \\
\hline
\end{tabular}




\begin{tabular}{l|l|l|l|l} 
No. & Parameter & Unit & Result & Standard $^{\mathbf{1}}$ \\
\hline 20. & Zinc as Zn & $\mathrm{mg} / \mathrm{kg}$ & 244 & 1000 \\
\hline 21. & Copper as $\mathrm{Cu}$ & $\mathrm{mg} / \mathrm{kg}$ & 206 & 300 \\
\hline 22. & Mercury as $\mathrm{Hg}$ & $\mathrm{mg} / \mathrm{kg}$ & 0.15 \\
\multicolumn{2}{r}{ Organic Fertilizer as per FCO (Amended Feb 2019) } &
\end{tabular}

The value of $\mathrm{C} / \mathrm{N}$ ratio, $\mathrm{OC}, \mathrm{TN}, \mathrm{K}_{2} \mathrm{O}, \mathrm{P}_{2} \mathrm{O}_{5}$, and $\mathrm{NPK}$ evidently portrays the shortcoming in terms of nutrient availability. Though it is highly enriched in organic carbon, the same can be effectively utilized as a soil preconditioner. Ayilara et al. (2020) [20] also reported a similar finding, where the city compost sourced from MSW lagged major plant nutrients.

\section{2. $R D F$ characterization.}

Processed trommel rejects constitute cloth, rexine, leather, jute, paper, plastics, coir, and other inert contributed to RDF. The fraction of inert was as high as $37.2 \%$ of the overall RDF mass, and it mostly constituted glass and sand. The combined weight of sand and glass fragments contributed $73.5 \%$ of the total inert, while the rest was stone and small brickbats. The higher level of silicon associated with the presence of glass and sand yielded siloxane and triggered the possibility of kiln corrosion. A detailed RDF analysis report is enclosed in Table 2 .

Table 2. Characteristics of RDF sourced from the legacy dump.

\begin{tabular}{l|l|l|l|l|l} 
No. & Parameter & Unit & Method & Result & $\begin{array}{l}\text { Standard- RDF- } \\
\text { Grade-I }\end{array}$ \\
\hline 1. & Moisture Content & $\%$ & $\begin{array}{l}\text { ASTM E790-15 } \\
\text { Standard }\end{array}$ & 16.82 & $<20 \%$ \\
\hline 2. & Net Calorific Value (NCV) & $\mathrm{kcal} / \mathrm{kg}$ & $\begin{array}{l}\text { ASTM E955- } \\
88(2009) \mathrm{e} 1 \\
\text { Standard }\end{array}$ & 1858 & $\begin{array}{l}>3000 \mathrm{KCal} / \mathrm{kg} \\
\text { net }\end{array}$ \\
\hline 3. & Ash & $\%$ & ASTM D5630-13 & 22 & $<15$ \\
\hline 4. & Chlorine & $\%$ & $\begin{array}{l}\text { ASTM E776-16 } \\
\text { Standard }\end{array}$ & 2.4 & $<1.0 \%$ \\
\hline 5. & Sulfur & $\%$ & $\begin{array}{l}\text { ASTM E775-15 } \\
\text { Standard }\end{array}$ & 3.6 & $<2 \%$
\end{tabular}

${ }^{1}$ Specifications based on American Society for Testing and Materials

The values explicitly portray that the quality of RDF is moderately lower, and higher salts concentration is extremely prevalent. With relatively lower NCV and high salt concentration, the above specimen will pose a corrosion threat to the kiln and be neglected as kiln feed or utilized after dilution with Grade III RDF quality. Further, such high ash generation will also induct high transportation and landfill charges.

\subsection{Leachate characterization.}

The Malkaram leachate lake results from prolonged, slow, and steady mixing of the legacy leachate through the existing fissure cracks in the sheath rock bottom profile. Apparently, the concentration of leachate is significantly lower due to the dilution. Samples were analyzed in triplicates, and the mean value is tabulated here in Table 3.

Table 3. Characteristics of Malkaram leachate.

\begin{tabular}{l|l|l|l|l} 
No. & Parameters & Units & Method & Result \\
\hline 1 & pH @ $25^{\circ} \mathrm{C}$ & - & APHA 4500 $\mathrm{H}^{+} \mathrm{B}$ & 7.89 \\
\hline 2 & Electrical Conductivity & $\mu \mathrm{Mhos} / \mathrm{cm}$ & APHA 2510 B & 53988 \\
\hline 3 & Total Dissolved Solids (TDS) & $\mathrm{mg} / \mathrm{L}$ & APHA 2540 C & 31554
\end{tabular}




\begin{tabular}{|c|c|c|c|c|}
\hline No. & Parameters & Units & Method & Result \\
\hline 4 & Chlorides as $\mathrm{Cl}^{-}$ & $\mathrm{mg} / \mathrm{L}$ & APHA $4500 \mathrm{Cl}-\mathrm{C}$ & 10826 \\
\hline 5 & Sulphates as $\mathrm{SO}^{-2}$ & $\mathrm{mg} / \mathrm{L}$ & APHA 4500 SO4-2 D & 510 \\
\hline 6 & Kjehldal Nitrogen & $\mathrm{mg} / \mathrm{L}$ & APHA $4500 \mathrm{~N}$ (org) B & 854 \\
\hline 7 & Ammonical Nitrogen & $\mathrm{mg} / \mathrm{L}$ & APHA $4500 \mathrm{NH} 3 \mathrm{~B}, \mathrm{C}$ & 820 \\
\hline 8 & Nitrates as $\mathrm{NO}_{3}-\mathrm{N}$ & $\mathrm{mg} / \mathrm{L}$ & APHA $4500 \mathrm{NO}^{-} \mathrm{B}$ & 130 \\
\hline 9 & Alkalinity as $\mathrm{CaCO}_{3}$ & $\mathrm{mg} / \mathrm{L}$ & APHA $2320 \mathrm{~B}$ & 5498 \\
\hline 10 & Calcium as $\mathrm{Ca}$ & $\mathrm{mg} / \mathrm{L}$ & APHA $3500 \mathrm{Ca}$ B & 456 \\
\hline 11 & Magnesium as Mg & $\mathrm{mg} / \mathrm{L}$ & APHA $3500 \mathrm{Mg}$ B & 140 \\
\hline 12 & Sodium as $\mathrm{Na}$ & $\mathrm{mg} / \mathrm{L}$ & APHA $3500 \mathrm{Na} \mathrm{B}$ & 6792 \\
\hline 13 & Potassium as $\mathrm{K}$ & $\mathrm{mg} / \mathrm{L}$ & APHA $3500 \mathrm{~K} \mathrm{~B}$ & 5254 \\
\hline 14 & Fluoride as $\mathrm{F}^{-}$ & $\mathrm{mg} / \mathrm{L}$ & APHA 4500 F- D & 3.56 \\
\hline 15 & Chemical Oxygen Demand & $\mathrm{mg} / \mathrm{L}$ & APHA $5220 \mathrm{~B}$ & 14556 \\
\hline 16 & $\begin{array}{l}\text { Biochemical Oxygen Demand } \\
\left(3 \text { day at } 27^{\circ} \mathrm{C}\right)\end{array}$ & $\mathrm{mg} / \mathrm{L}$ & IS 3025 (P-44) & 4388 \\
\hline 17 & Oil \& Grease & $\mathrm{mg} / \mathrm{L}$ & APHA 5743 B & $<10$ \\
\hline 18 & Lead as $\mathrm{Pb}$ & $\mathrm{mg} / \mathrm{L}$ & APHA $3120 \mathrm{~B}$ & 0.21 \\
\hline 19 & Cadmium as $\mathrm{Cd}$ & $\mathrm{mg} / \mathrm{L}$ & APHA 3120 B & $<0.003$ \\
\hline 20 & Total Chromium as $\mathrm{Cr}$ & $\mathrm{mg} / \mathrm{L}$ & APHA 3120 B & 0.24 \\
\hline 21 & Chromium as $\mathrm{Cr}+6$ & $\mathrm{mg} / \mathrm{L}$ & APHA $3500 \mathrm{Cr} B$ & $<0.05$ \\
\hline 22 & Nickel as Ni & $\mathrm{mg} / \mathrm{L}$ & APHA 3120 B & 0.51 \\
\hline 23 & Zinc as $\mathrm{Zn}$ & $\mathrm{mg} / \mathrm{L}$ & APHA 3120 B & 0.62 \\
\hline 24 & Manganese as Mn & $\mathrm{mg} / \mathrm{L}$ & APHA 3120 B & 0.28 \\
\hline 25 & Copper as $\mathrm{Cu}$ & $\mathrm{mg} / \mathrm{L}$ & APHA 3120 B & $<0.1$ \\
\hline 26 & Mercury as $\mathrm{Hg}$ & $\mu \mathrm{g} / \mathrm{L}$ & APHA 3120 B & $<0.1$ \\
\hline 27 & Arsenic as As & $\mathrm{mg} / \mathrm{L}$ & APHA 3120 B & $<0.2$ \\
\hline 28 & Cyanide as $\mathrm{CN}-$ & $\mathrm{mg} / \mathrm{L}$ & APHA $4500 \mathrm{CN}-\mathrm{E}$ & $<0.1$ \\
\hline 29 & $\begin{array}{l}\text { Phenolic compounds As } \\
\text { Phenols }\end{array}$ & $\mathrm{mg} / \mathrm{L}$ & APHA $5530 \mathrm{D}$ & $<0.001$ \\
\hline 30 & Iron as $\mathrm{Fe}$ & $\mathrm{mg} / \mathrm{L}$ & APHA $3500 \mathrm{Fe} \mathrm{B}$ & 25.4 \\
\hline 31 & Iron as $\mathrm{Fe}^{+3}$ & $\mathrm{mg} / \mathrm{L}$ & APHA $3500 \mathrm{Fe} \mathrm{B}$ & $<0.2$ \\
\hline 32 & Sulphide as $\mathrm{S}^{-2}$ & $\mathrm{mg} / \mathrm{L}$ & APHA $4500 \mathrm{~S} 2 \mathrm{~F}$ & 1.92 \\
\hline
\end{tabular}

The metal concertation and rest of the parameter values are well within the secondary treatment influent range, except for TDS. Thus, a modular aerobic biological treatment unit such as moving bed biofilm bioreactor (MBBR) or membrane bioreactor (MBR) would be a well-suited pick. However, a reverse osmosis (RO) system needs to be installed to eliminate the high TDS content. The permeate of RO can be reused back into the system, whereas the reject can be converted into dried powder through forced evaporation mechanisms. The higher concentration of salts in RDF collaterally justifies the elevated TDS level in leachate. In a leachate impact assessment study performed by El-Salam and Abu-Zuid (2015) [21] the reported BOD/COD ratio of 0.69 is greater than double the value of 0.301 reported in Table 3 . Though the difference in both the values is quite high, it is relatable and justifiable by the huge age difference of the source waste. The primarily characterized data is fresh leachate generated from regular MSW, while the latter is from a decade-old waste that barely has any unstabilized organic content.

\subsection{Groundwater contamination.}

The obvious reason for downward leachate infiltration and osmotic movement facilitates groundwater contamination. Both surface and subsurface water samples were collected within the dump yard and the buffer zone and analyzed using the standard methods. The results are portrayed in Table 4. 
Table 4. Characteristics of in and around surface and subsurface water.

\begin{tabular}{|c|c|c|c|c|c|c|}
\hline \multirow[b]{2}{*}{ No. } & \multirow[b]{2}{*}{ Parameters } & \multirow[b]{2}{*}{ Units } & \multirow[b]{2}{*}{ Method } & \multicolumn{2}{|c|}{ Water samples } & \multirow[b]{2}{*}{ Standard } \\
\hline & & & & Borewell & $\begin{array}{c}\text { Surface } \\
\text { water } \\
\text { sample }\end{array}$ & \\
\hline 1 & $\mathrm{pH}$ & -- & APHA $4500 \mathrm{H}+\mathrm{B}$ & 8.24 & 7.82 & $6.5-8.5$ \\
\hline 2 & Total Dissolved Solids & $\mathrm{mg} / \mathrm{L}$ & APHA $2540 \mathrm{C}$ & 3956 & 2054 & 500 \\
\hline 3 & Total Alkalinity as $\mathrm{CaCo}_{3}$ & $\mathrm{mg} / \mathrm{L}$ & APHA 2320 B & 322 & 328 & \\
\hline 4 & Total hardness as $\mathrm{CaCo}_{3}$ & $\mathrm{mg} / \mathrm{L}$ & APHA $2340 \mathrm{C}$ & 2398 & 1144 & 300 \\
\hline 5 & Calcium as $\mathrm{Ca}^{+2}$ & $\mathrm{mg} / \mathrm{L}$ & APHA $3500 \mathrm{Ca}$ & 525 & 246 & \\
\hline 6 & Residual free chlorine as $\mathrm{Cl}^{-}$ & $\mathrm{mg} / \mathrm{L}$ & APHA $4500 \mathrm{Cl}$ & 0 & 0 & \\
\hline 7 & Nitrates as $\mathrm{NO}_{3}-\mathrm{N}$ & $\mathrm{mg} / \mathrm{L}$ & APHA 4500 NO3-B & 31.2 & 62.3 & 45 \\
\hline 8 & Fluoride as $\mathrm{F}^{-}$ & $\mathrm{mg} / \mathrm{L}$ & APHA $4500 \mathrm{~F}$ & 1.27 & 0.9 & \\
\hline 9 & Chlorides as $\mathrm{Cl}^{-}$ & $\mathrm{mg} / \mathrm{L}$ & APHA $4500 \mathrm{Cl}-\mathrm{B}$ & 1838 & 684 & 250 \\
\hline 10 & Sulphate as $\mathrm{SO}_{4}$ & $\mathrm{mg} / \mathrm{L}$ & APHA 4500 SO4 & 138 & 152 & 200 \\
\hline 11 & Phenolic Compounds & $\mathrm{mg} / \mathrm{L}$ & APHA $5530 \mathrm{D}$ & $<0.1$ & $<0.001$ & 0.002 \\
\hline 12 & Cyanide as $\mathrm{CN}$ & $\mathrm{mg} / \mathrm{L}$ & APHA $4500 \mathrm{CN}-\mathrm{E}$ & $<0.2$ & $<0.1$ & 0.05 \\
\hline 13 & Arsenic as As & $\mathrm{mg} / \mathrm{L}$ & APHA 3120 B & $<0.05$ & $<0.05$ & 0.01 \\
\hline 14 & Cadmium as $\mathrm{Cd}$ & $\mathrm{mg} / \mathrm{L}$ & APHA 3120 B & $<0.003$ & $<0.003$ & 0.01 \\
\hline 15 & Copper as $\mathrm{Cu}$ & $\mathrm{mg} / \mathrm{L}$ & APHA 3120 B & 0.24 & $<0.05$ & 0.05 \\
\hline 16 & Lead as $\mathrm{Pb}$ & $\mathrm{mg} / \mathrm{L}$ & APHA 3120 B & 0.28 & $<0.01$ & 0.05 \\
\hline 17 & Zinc as $\mathrm{Zn}$ & $\mathrm{mg} / \mathrm{L}$ & APHA 3120 B & $<0.5$ & $<0.5$ & 5 \\
\hline 18 & Nickel & $\mathrm{mg} / \mathrm{L}$ & APHA 3120 B & $<0.02$ & $<0.02$ & 0.02 \\
\hline 19 & Manganese as Mn & $\mathrm{mg} / \mathrm{L}$ & APHA 3120 B & 0.26 & $<0.1$ & \\
\hline 20 & Iron as $\mathrm{Fe}$ & $\mathrm{mg} / \mathrm{L}$ & APHA $3500 \mathrm{Fe}$ B & $<0.2$ & $<0.2$ & 0.3 \\
\hline 21 & Chromium & $\mathrm{mg} / \mathrm{L}$ & APHA 3120 B & $<0.05$ & $<0.05$ & 0.05 \\
\hline 22 & Chromium as $\mathrm{Cr}^{+6}$ & $\mathrm{mg} / \mathrm{L}$ & SW-846 $7196 \mathrm{~B}$ & $<0.05$ & $<0.05$ & \\
\hline 23 & Boron & $\mathrm{mg} / \mathrm{L}$ & APHA 3120 B & $<0.5$ & $<0.1$ & \\
\hline 24 & Oil \& Grease & $\mathrm{mg} / \mathrm{L}$ & APHA 5520 B & $<1.0$ & $<1$ & \\
\hline 25 & Odour & & -- & & & \\
\hline 26 & Dissolved Oxygen & $\mathrm{mg} / \mathrm{L}$ & APHA $4500 \mathrm{O}$ & 3.5 & 5.1 & $>4.0$ \\
\hline 27 & Turbidity & NTU & APHA 2130 B & & 25 & \\
\hline 28 & Mercury as $\mathrm{Hg}$ & $\mathrm{mg} / \mathrm{L}$ & APHA $3120 \mathrm{~B}$ & $<0.1$ & $<0.1$ & 0.001 \\
\hline
\end{tabular}

The slightly alkaline $\mathrm{pH}$ of the borewell sample is an indication of the ongoing anaerobic process. The dissolved oxygen value of $3.5 \mathrm{mg} / \mathrm{L}$ further validates the correlation. Higher TDS and hardness values are self-indicative of elevated salt concentration in source waste. Eventually, the same interfered with the RDF quality. Positively in the case of all the parameters, a successive decrement in pollution concentration has been spotted from the dump ground towards the buffer zone. In a similar study conducted by Singh et al. (2016) [22] at Varanasi, Uttar Pradesh, the reported concentration of the parameters is significantly higher than reported in Table 4. The basic reason behind variation is the dissimilarities of the local soil profile. The sandy and clay loam soil profile of Varanasi allows a greater rate of percolation and infiltration.

In comparison, the bottom sheath rock profile at Jawahar Nagar permits only a minute to little percolation rate. The difference in percolation rate is directly correlated to the concentration levels in this case. Contrarily, Kurakalva et al. (2016) [23] reported muchelevated pollutant concertation in ground and surface water for a study conducted at the same site in 2016. The higher concentration is relatable to the fact of the non-closure of the open dump back then. Capping activity had at Jawahar Nagar gained its pace from 2018 onwards, and capping for the primary section of 70 acres was concluded only during mid-2019. Due to the decrement in runoff and percolation, both surface and subsurface water quality have improved drastically. 


\subsection{Impact assessment.}

The odor and groundwater contamination are two of the primary issues that triggered a massive public agitation initially. The root causes of both the issues are identified as rainwater percolation and anaerobic digestion, respectively. Eventually, the completion of the capping process would resolve both problems effectively. Other non-tangential impacts include nausea; headache; irritation of the eye, nasal cavity, and throat; diarrhoeal diseases; vector-borne disease, cattle toxicity, etc. Scientific capping can easily cater as a wholesome solution for all [17]. Yu et al. (2018) [24] had performed an extensive study to comprehend the relativity of respiratory sickness and MSW-borne air pollution. The study made a couple of dreadful revelations such as gases released due to the anaerobic digestion of MSW such as methane, hydrogen sulfide, and ammonia incur detrimental impact on Lysozyme and secretory immunoglobulin A (SIgA). While $\mathrm{SO}_{2}$ was reported as the lung capacity and functionality reducer. Further, the same research group executed a gender-specific study that revealed that air pollution impacts more severely on male children than females and retards immune functions.

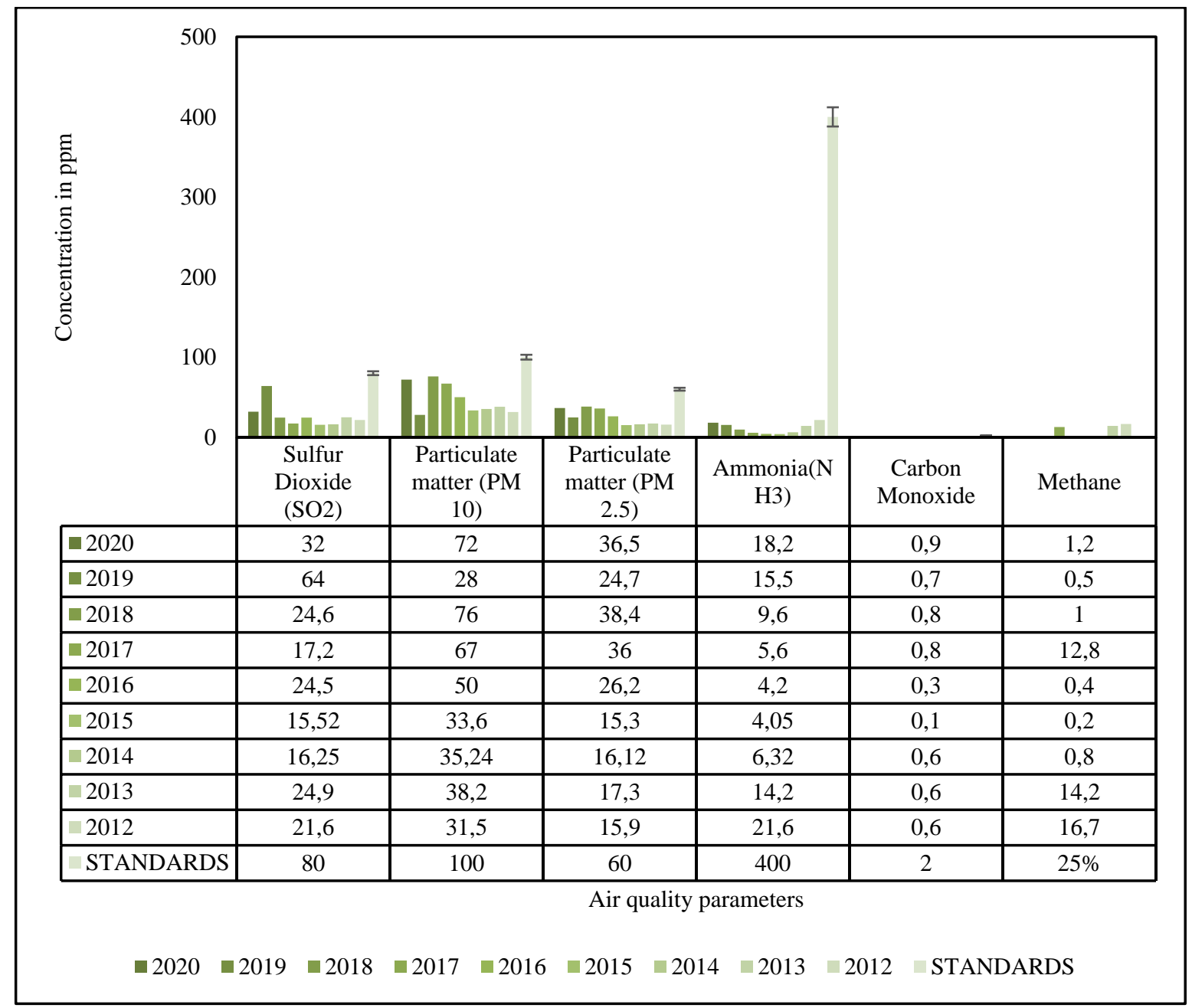

Figure 3. Consolidated report of ambient air quality between 2012 to 2020 .

Presently, the area of 351 acres has been developed as Asia's one of the largest stateof-the-art municipal solid waste processing and disposal facilities by Ramky Enviro Engineers Limited. This ensured zero dumping and no further environmental interventions. As legal compliance, the facility monitors groundwater quality and ambient air quality in and around 
the facility monthly to ensure biosafety. The variation in concentration of various monitoring parameters between 2012 to 2020 is summarized in Figure 3.

The concentration of each of the parameters is showcased in ppm, and a standard equipment error was settled at 3\% for respirable dust sampler and multi-gas analyzer [25]. Although all parameter values have gradually increased except for methane, the facility still managed to maintain them well under the regulatory limits. The decrement in methane concentration is directly correlated to the practice of aerobic composting and aeration-based secondary treatment that prevented the formation of the anaerobic atmosphere and henceforth methane generation. While for the rest of the parameters, the increment in values is quite substantial and predictable due to the sudden escalation in MSW generation in the past decade in correlation with Gross domestic product (GDP) enhancement. The observed and interpreted impacts due to the elevated pollutant level align with the georeferenced findings reported by Deshmukh and Aher (2016) [26] based on a study conducted at Sangamner, Maharashtra.

\section{Conclusions}

The study critically analyzed and investigated every techno-environmental and socioeconomic aspect correlated to open dumping. The bench-scale experimentation revealed that the single-liner scientific capping efficiency is fair enough to eliminate any further rainwater infiltration. However, it has no control over the generation of leachate due to the inherent moisture. The internal moisture-related issue was anyhow compensated with pertinent compaction before disposal of the waste. Contrarily, both the products derived through the biomining process, namely, compost and RDF, lagged quality due to scantier nutrient content and higher salt and silicon content, respectively. Besides, impact assessment studies concede that the pollutant concentration in groundwater in and around the plant has drastically diminished post-July 2019 due to the partial completion of waste capping. It also abetted lowering the dust and odor issues relatively in the surrounding.

\section{Funding}

The authors would like to thank EPTRI and Hyderabad Integrated MSW Limited (HIMSWL) for internally funding the study.

\section{Acknowledgments}

The authors would like to sincerely acknowledge GHMC, HIMSWL, and Ramky Enviro Engineers Limited for enabling us to pursue the sample collection and other necessary onsite activities. Further, the authors would like to register profound acknowledgment to EPTRI for supporting us with the essential experimental facilities.

\section{Conflicts of Interest}

The authors declare no conflict of interest.

\section{References}

1. Scott, K. Microfiltration. In Handbook of Industrial Membranes, Scott, K. Eds.; Elsevier Science: Netherlands, 1995, 373-429, https://doi.org/10.1016/B978-185617233-2/50010-6.

2. Bhat, S.A.; Singh, J.; Singh, K.; Vig, A.P. Genotoxicity monitoring of industrial wastes using plant bioassays and management through vermitechnology: A review. Agriculture and Natural Resources 2017, 51, 325-337, 
https://doi.org/10.1016/j.anres.2017.11.002.

3. Sethurajan, M.; van Hullebusch, E.D.; Nancharaiah, Y.V. Biotechnology in the management and resource recovery from metal bearing solid wastes. Recent advances. J Environ Manage. 2018, 211, 138-153, https://doi.org/10.1016/j.jenvman.2018.01.035.

4. Sharma, A.; Gupta, A.K.; Ganguly, R. Impact of open dumping of municipal solid waste on soil properties in mountainous region. Journal of Rock Mechanics and Geotechnical Engineering 2018, 10, 725-739, https://doi.org/10.1016/j.jrmge.2017.12.009.

5. Jayawardhana, Y.; Kumarathilaka, P.; Herath, I.; Vithanage, M. Municipal Solid Waste Biochar for Prevention of Pollution from Landfill Leachate. In Environmental Materials and Waste, Prasad, M.N.V.; Shih, K. Eds.; Academic Press, United States, 2016, 117-148, https://doi.org/10.1016/B978-0-12-8038376.00006-8.

6. Mir, I.S.; Cheema, P.P.S.; Singh, S.P. Implementation analysis of solid waste management in Ludhiana city of Punjab. Environmental Challenges 2021, 2, 100023, https://doi.org/10.1016/j.envc.2021.100023.

7. Chakrabarti, M.; Dubey, A. Remediation Techniques, for Open Dump Sites, used for the Disposal of Municipal Solid Waste in India. Journal of Basic and Applied Engineering Research 2015, 2, 1510-1513.

8. Thakare, S.; Nandi, S. Study on Potential of Gasification Technology for Municipal Solid Waste (MSW) in Pune City. Energy Procedia 2016, 90, 509-517, https://doi.org/10.1016/j.egypro.2016.11.218.

9. Kaksonen, A. H.; Boxall, N. J.; Bohu, T.; Usher, K.; Morris, C.; Wong, P. Y.; Cheng, K. Y. Recent Advances in Biomining and Microbial Characterisation. Solid State Phenomena 2017, 262, 33-37, https://doi.org/10.4028/www.scientific.net/ssp.262.33.

10. Jerez, C.A. Bioleaching and biomining for the industrial recovery of metals. In Reference module in life sciences, 3rd ed.; Moo-Young, M., Eds.; Elsevier: Amsterdam, United States, 2017; 3, 1-14, https://doi.org/10.1016/B978-0-12-809633-8.09185-8.

11. Banerjee, I.; Burrell, B.; Reed, C.; West, A.C.; Banta, S. Metals and minerals as a biotechnology feedstock: engineering biomining microbiology for bioenergy applications. Curr Opin Biotechnol. 2017, 45, 144-155, https://doi.org/10.1016/j.copbio.2017.03.009.

12. Venkiteela, L.K. Status and challenges of solid waste management in Tirupati city. Materials Today: Proceedings 2020, 33, 470-474, https://doi.org/10.1016/j.matpr.2020.05.044.

13. Mehta, Y.D.; Shastri, Y.; Joseph, B. Economic analysis and life cycle impact assessment of municipal solid waste (MSW) disposal: A case study of Mumbai, India. Waste Management \& Research 2018, 36, 1177 1189, https://doi.org/10.1177/0734242X18790354.

14. Ashootosh, M.; Periyaswamy, L.; Sunil, K.; Hiroshan, H. Mining for recovery as an option for dumpsite rehabilitation: case study from Nagpur, India. Journal of Environmental Engineering and Science 2020, 15, 52-60, https://doi.org/10.1680/jenes.19.00021.

15. Berkun, M.; Aras, E.; Nemlioglu, S. Disposal of solid waste in Istanbul and along the Black Sea coast of Turkey. Waste Manag. 2005, 25, 847-55, https://doi.org/10.1016/j.wasman.2005.04.004.

16. Al-Ghouti, M.A.; Khan, M.; Nasser, M.S.; Al-Saad, K.; Heng, O.E. Recent advances and applications of municipal solid wastes bottom and fly ashes: Insights into sustainable management and conservation of resources. Environmental Technology \& Innovation 2021, 21, 101267 , https://doi.org/10.1016/j.eti.2020.101267.

17. Mohan S.; Joseph C.P. Biomining: An Innovative and Practical Solution for Reclamation of Open Dumpsite. In Recent Developments in Waste Management. Lecture Notes in Civil Engineering, Kalamdhad, A., Eds.; Springer, Singapore, 2020; 57, 167-178, https://doi.org/10.1007/978-981-15-0990-2_12.

18. Cortellazzo, G.; Mandaglio, M.C.; Busana, S. Favaretti, M.; Moraci, N. A New Approach for the Design, Construction and Control of Compacted Mineral Liners of a MSW Landfill Capping. Int. J. of Geosynth. and Ground Eng. 2020, 6, 49, https://doi.org/10.1007/s40891-020-00234-X.

19. Ashford, S.A.; Visvanathan, C.; Husain, N.; Chomsurin, C. Design and construction of engineered municipal solid waste landfills in Thailand. Waste Management \& Research 2000, 18, 462-470, https://doi.org/10.1177/0734242X0001800507.

20. Ayilara, M.S.; Olanrewaju, O.S.; Babalola, O.O.; Odeyemi, O. Waste Management through Composting: Challenges and Potentials. Sustainability 2020, 12, 4456, https://doi.org/10.3390/su12114456.

21. El-Salam, M.M.A.; Abu-Zuid, G.I. Impact of landfill leachate on the groundwater quality: A case study in Egypt. Journal of Advanced Research 2015, 6, 579-586, https://doi.org/10.1016/j.jare.2014.02.003. 
22. Singh, S.; Raju, N.J.; Gossel, W.; Wycisk, P. Assessment of pollution potential of leachate from the municipal solid waste disposal site and its impact on groundwater quality, Varanasi environs, India. Arab $J$ Geosci 2016, 9, 131, https://doi.org/10.1007/s12517-015-2131-x.

23. Kurakalva, R.M.; Aradhi, K.K.; Mallela, K.Y.; Venkatayogi, S. Assessment of Groundwater Quality in and around the Jawaharnagar Municipal Solid Waste Dumping Site at Greater Hyderabad, Southern India. Procedia Environmental Sciences 2016, 35, 328-336, https://doi.org/10.1016/j.proenv.2016.07.013.

24. Yu, Y.; Yu, Z.; Sun, P.; Lin, B.; Li, L.; Wang, Z.; Ma, R.; Xiang, M.; Li, H.; Guo, S. Effects of ambient air pollution from municipal solid waste landfill on children's non-specific immunity and respiratory health. Environmental Pollution 2018, 236, 382-390, https://doi.org/10.1016/j.envpol.2017.12.094.

25. Taheri, M.; Gholamalifard, M.; Ghazizade, M.J.; Rahimoghli, S. Environmental impact assessment of municipal solid waste disposal site in Tabriz, Iran using rapid impact assessment matrix. Impact Assessment and Project Appraisal 2014, 32, 162-169, https://doi.org/10.1080/14615517.2014.896082.

26. Deshmukh, K.K.; Aher, S.P. Assessment of the Impact of Municipal Solid Waste on Groundwater Quality near the Sangamner City using GIS Approach. Water Resour Manage 2016, 30, 2425-2443, https://doi.org/10.1007/s11269-016-1299-5. 